2016

\title{
Caddo Ceramic Vessels from the S. E. Watson (41RR8) and Hook's Ferry (41RR9) Sites, Red River County, Texas
}

Timothy K. Perttula

Heritage Research Center, Stephen F. Austin State University

Mark Walters

Heritage Research Center, Stephen F. Austin State University

Follow this and additional works at: https://scholarworks.sfasu.edu/ita

Part of the American Material Culture Commons, Archaeological Anthropology Commons, Environmental Studies Commons, Other American Studies Commons, Other Arts and Humanities Commons, Other History of Art, Architecture, and Archaeology Commons, and the United States History Commons

Tell us how this article helped you.

This Article is brought to you for free and open access by the Center for Regional Heritage Research at SFA ScholarWorks. It has been accepted for inclusion in Index of Texas Archaeology: Open Access Gray Literature from the Lone Star State by an authorized editor of SFA ScholarWorks. For more information, please contact cdsscholarworks@sfasu.edu. 
Caddo Ceramic Vessels from the S. E. Watson (41RR8) and Hook's Ferry (41RR9) Sites, Red River County, Texas

\section{Creative Commons License}

\section{(c) (1) \&}

This work is licensed under a Creative Commons Attribution-NonCommercial 4.0 International License 


\title{
Caddo Ceramic Vessels from the S. E. Watson (41RR8) and Hook's Ferry (41RR9) Sites, Red River County, Texas
}

\author{
Timothy K. Perttula and Mark Walters
}

\section{INTRODUCTION}

There are 15 ancestral Caddo ceramic vessels from the S. E. Watson $(n=13)$ and Hook's Ferry $(n=2)$ sites in the collections of the Texas Archeological Research Laboratory at The University of Texas at Austin. The S. E. Watson site is a Caddo mound center, village, and cemetery on Pecan Bayou near its confluence with the Red River (Figure 1). Another Caddo mound was reported at nearby 41RR67, on the Chapman Plantation, although it may have been destroyed by Red River flooding. The Hook's Ferry site (41RR9) is situated in the Red River floodplain just east of the Jonesborough site (41RR15), north of Salt Well Slough, and ca. $3 \mathrm{~km}$ upstream from the large village and mound center at the Sam Kaufman site (41RR16).

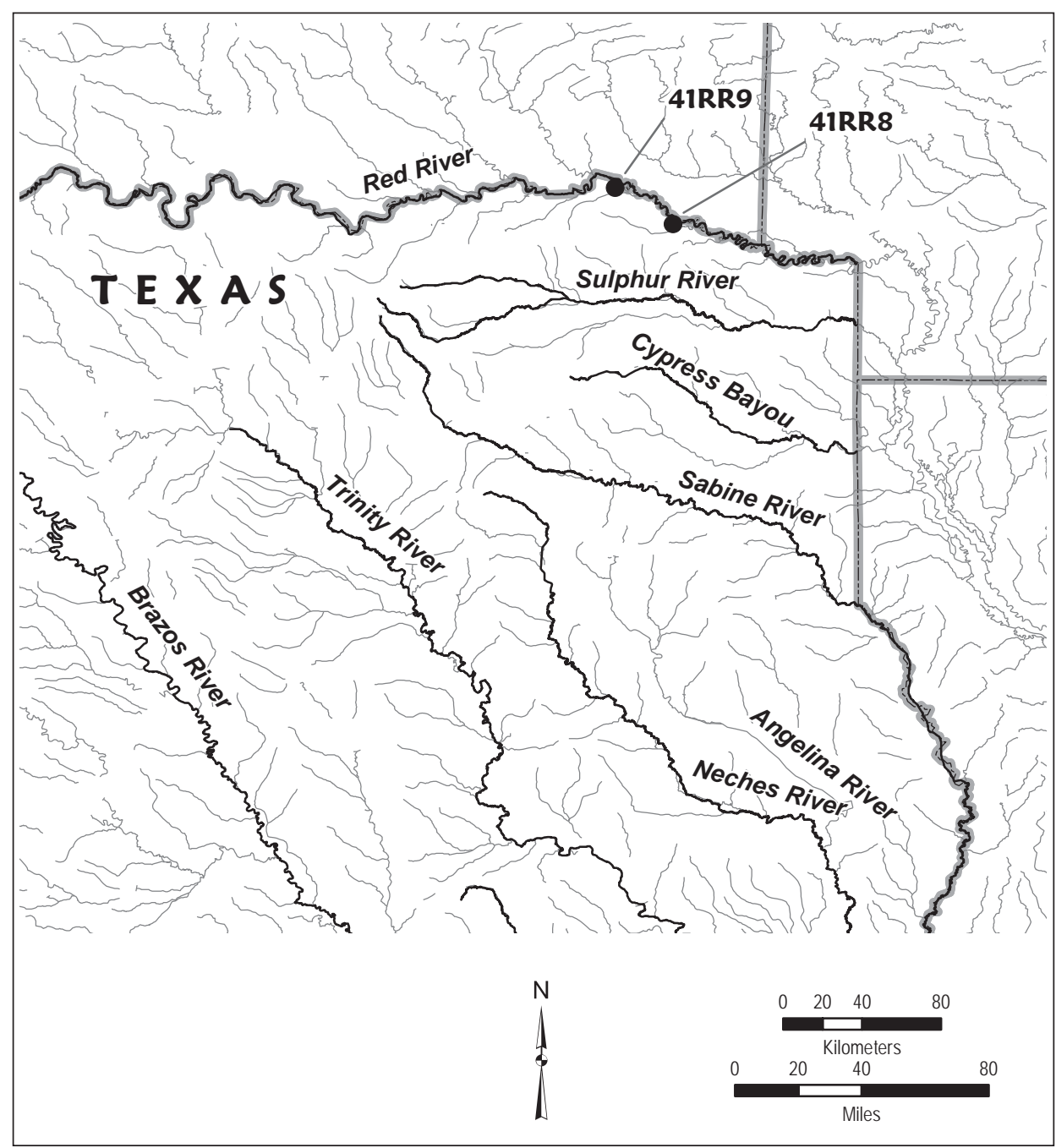

Figure 1. Location of the S. E. Watson (41RR8) and Hook's Ferry (41RR9) sites in East Texas. 


\section{S. E. Watson Site (41RR8) Vessel Documentation}

The 13 vessels from the S. E. Watson site, also known as the J. O. Chapman Plantation, in the TARL collections were purchased from Mr. S. E. Watson by UT in May 1927. They appear to be funerary offerings primarily from post-A.D. 1550 Caddo Indian burials, but several vessels suggest use of the site in Middle Caddo period times as well. The Watson family found these vessels (actually a total of 24 vessels in all were found in 1927) after the cave in of the bank of the Red River after a flood, as well as a ceramic elbow pipe.

SITE NAME OR SITE NUMBER: S. E. Watson

VESSEL NO.: 1

VESSEL FORM: Jar

NON-PLASTICS AND PASTE: grog

RIM AND LIP FORM: Everted rim and rounded lip

CORE COLOR: B (fired and cooled in a reducing environment)

INTERIOR SURFACE COLOR: very dark grayish-brown

EXTERIOR SURFACE COLOR: very dark grayish-brown; fire clouds on the body

WALL THICKNESS (IN MM): rim, 7.2 mm

INTERIOR SURFACE TREATMENT: smoothed

EXTERIOR SURFACE TREATMENT: smoothed on the body

HEIGHT (IN CM): 16.5

ORIFICE DIAMETER (IN CM): 16.6

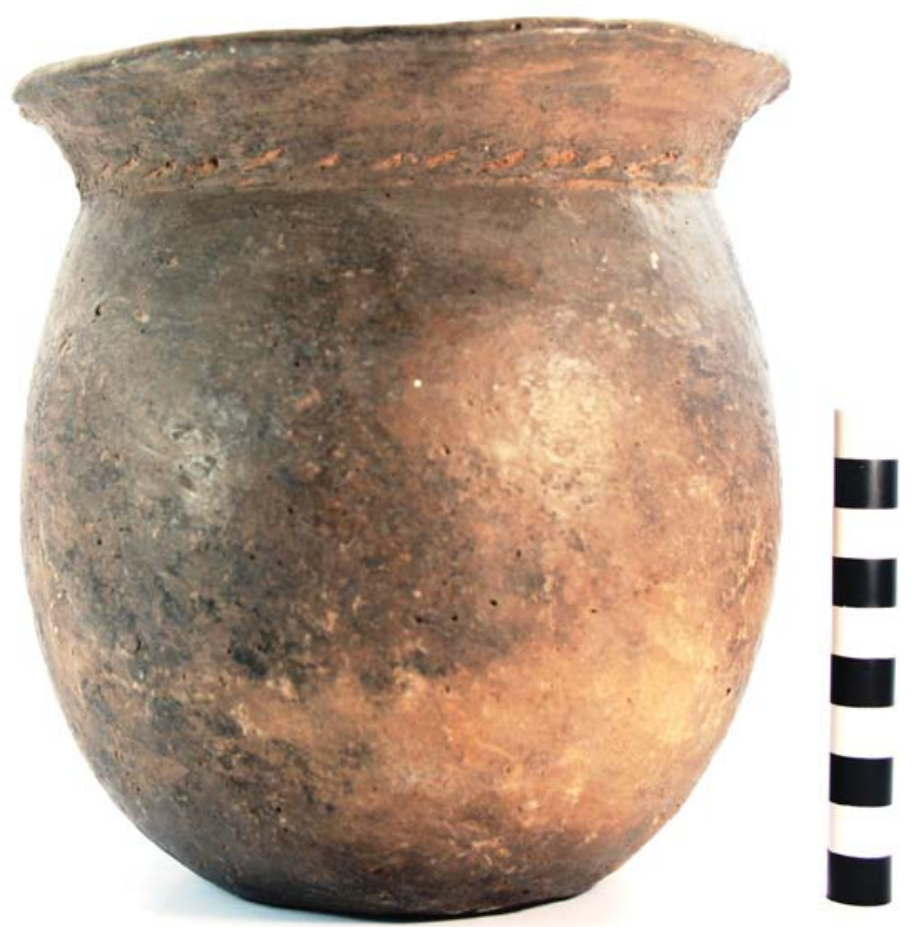

Figure 2. Emory Punctated jar (Vessel 1) from the S. E. Watson site.

DIAMETER AT BOTTOM OF RIM OR NECK (IN CM): 15.8

BASE DIAMETER (IN CM) AND SHAPE OF BASE: 7.6; circular and flat

ESTIMATED VOLUME (IN LITERS): 2.5

DECORATION (INCLUDING MOTIF AND ELEMENTS WHEN APPARENT): The rim is decorated with a single row of diagonal tool punctations above the rim-body juncture (Figure 2).

PIGMENT USE AND LOCATION ON VESSEL: none

TYPE AND VARIETY (IF KNOWN): Emory Punctated 
SITE NAME OR SITE NUMBER: S. E. Watson

VESSEL NO.: 2

VESSEL FORM: Bowl with a hub-cap shape (Figure 3a)

NON-PLASTICS AND PASTE: grog

RIM AND LIP FORM: Inverted rim and rounded lip

CORE COLOR: B (fired and cooled in a reducing environment)

INTERIOR SURFACE COLOR: black; fire clouds on the body

EXTERIOR SURFACE COLOR: black; fire clouds on the body

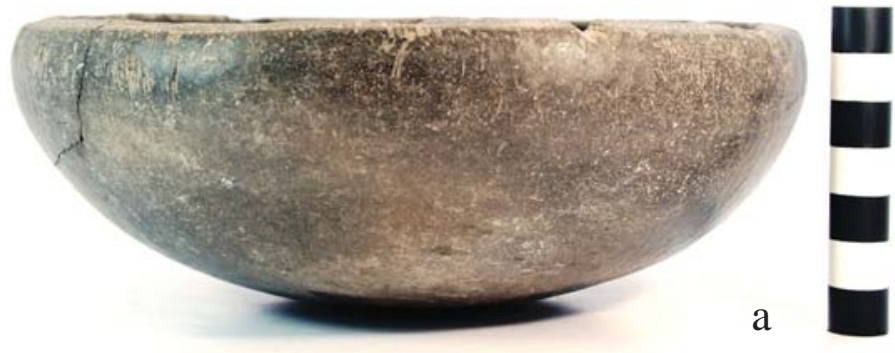

WALL THICKNESS (IN MM):

rim, $4.6 \mathrm{~mm}$

Figure 3. Simms Engraved, var. Darco carinated bowl from the S. E. Watson site: a, side view; b, top down view.

INTERIOR SURFACE TREATMENT: smoothed

EXTERIOR SURFACE TREATMENT: smoothed

HEIGHT (IN CM): 7.2

ORIFICE DIAMETER (IN CM): 16.6

DIAMETER AT BOTTOM OF RIM

OR NECK (IN CM): N/A

BASE DIAMETER (IN CM) AND

SHAPE OF BASE: 8.0; circular and flat

ESTIMATED VOLUME (IN LITERS): 0.5

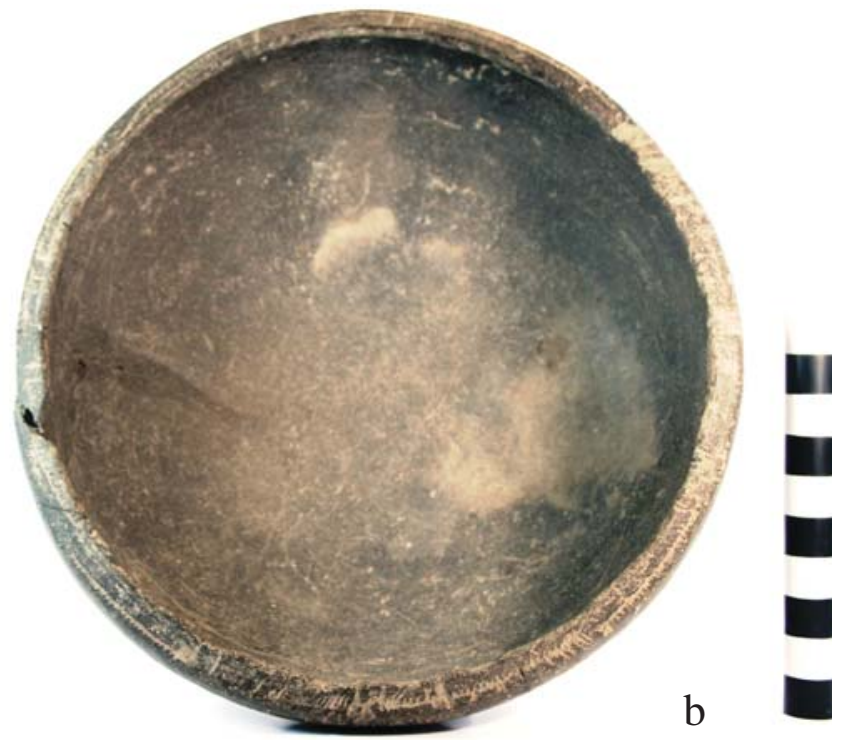

DECORATION (INCLUDING MOTIF AND ELEMENTS WHEN APPARENT): The rim area of the vessel has been divided into five panels by sets of two vertical engraved lines. The panels have an upper triangular element with upward-pointing tick marks and a lower vertical and horizontal engraved element with upwardpointing linear tick marks (Figure $3 b$ ).

PIGMENT USE AND LOCATION ON VESSEL: none

TYPE AND VARIETY (IF KNOWN): Simms Engraved, var. Darco 
SITE NAME OR SITE NUMBER: S. E. Watson

VESSEL NO.: 3

VESSEL FORM: Bottle with a spool neck

NON-PLASTICS AND PASTE: grog

RIM AND LIP FORM: Direct rim and rounded lip

CORE COLOR: $F$ (fired in a reducing environment and cooled in the open air)

INTERIOR SURFACE COLOR:

yellowish-brown

EXTERIOR SURFACE COLOR:

yellowish-brown; fire clouds

on the neck, body, and base

WALL THICKNESS (IN MM):

rim, $4.5 \mathrm{~mm}$

INTERIOR SURFACE

TREATMENT: none

EXTERIOR SURFACE

TREATMENT: smoothed

HEIGHT (IN CM): 15.0

ORIFICE DIAMETER (IN CM): 3.8

DIAMETER AT BOTTOM OF RIM

OR NECK (IN CM): 5.0; maximum

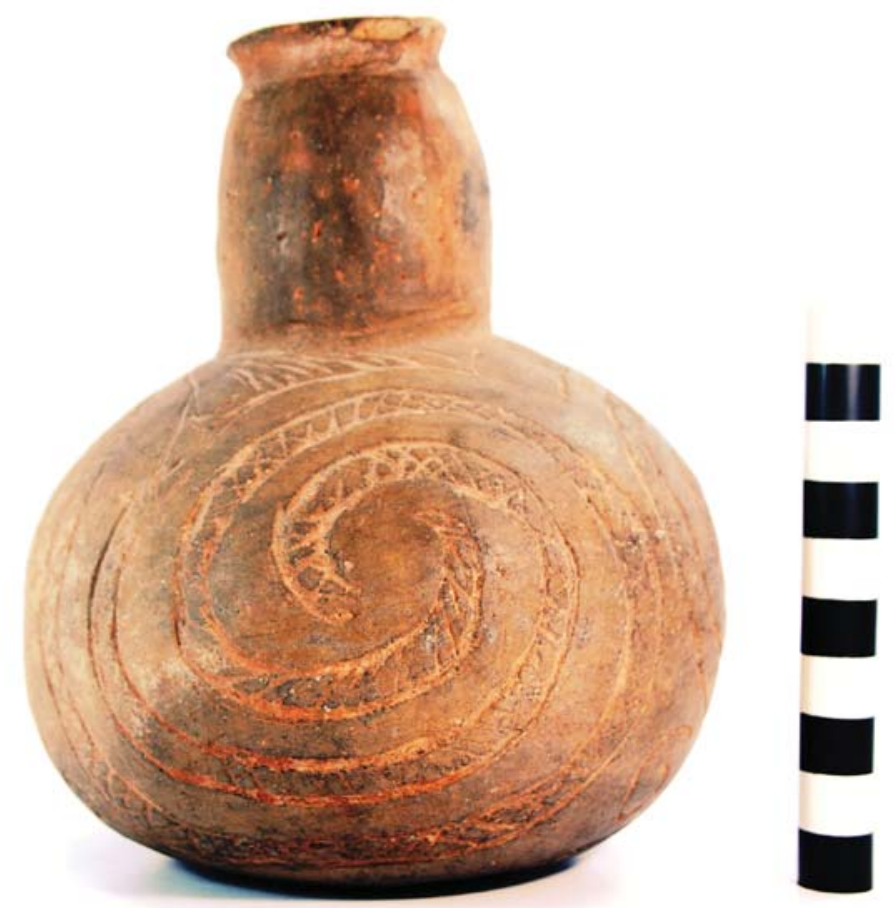

Figure 4. cf. Hodges Engraved bottle from the S. E. Watson site.

body diameter of $13.0 \mathrm{~cm}$.

BASE DIAMETER (IN CM) AND SHAPE OF BASE: 7.4; circular and flat

ESTIMATED VOLUME (IN LITERS): 0.4

DECORATION (INCLUDING MOTIFAND ELEMENTS WHENAPPARENT): The upper part of the vessel body has a narrow engraved zone with diagonal and diagonal opposed engraved lines as well as triangular projections. The lower part of the vessel body has a narrow rectangular engraved zone filled with cross-hatched lines. The area between these zones has four graceful curvilinear scroll zones that wrap around each other and end in hooked arm elements; the scroll zones have hatched or cross-hatched lines (Figure 4). Between the bottom parts of each of these scrolls are single hooked lines.

PIGMENT USE AND LOCATION ON VESSEL: none

TYPE AND VARIETY (IF KNOWN): cf. Hodges Engraved 
SITE NAME OR SITE NUMBER: S. E. Watson

VESSEL NO.: 4

VESSEL FORM: Bowl

NON-PLASTICS AND PASTE: shell

RIM AND LIP FORM: Everted rim and rounded, exterior folded lip

CORE COLOR: $\mathrm{F}$ (fired in a reducing environment and cooled in the open air)

INTERIOR SURFACE COLOR:

brown; fire clouds on the body

EXTERIOR SURFACE COLOR:

reddish-brown; fire clouds

on the body and base

WALL THICKNESS (IN MM):

rim, $3.8 \mathrm{~mm}$

INTERIOR SURFACE

TREATMENT: smoothed

EXTERIOR SURFACE

TREATMENT: smoothed

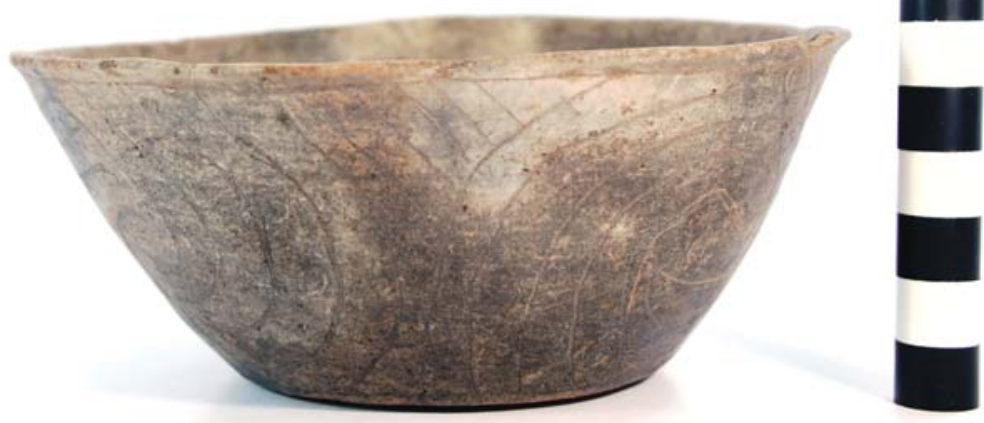

HEIGHT (IN CM): 6.0

Figure 5. Taylor Engraved bowl from the S. E. Watson site.

ORIFICE DIAMETER (IN CM): 13.8

DIAMETER AT BOTTOM OF RIM OR NECK (IN CM): N/A

BASE DIAMETER (IN CM) AND SHAPE OF BASE: 7.3; circular and flat

ESTIMATED VOLUME (IN LITERS): 0.3

DECORATION (INCLUDINGMOTIFANDELEMENTS WHENAPPARENT): The vessel rim and body has four sets of engraved hooked arm elements and concentric curvilinear scroll lines. The outermost curvilinear engraved line has a triangle element filled with a series of diagonal lines (Figure 5).

PIGMENT USE AND LOCATION ON VESSEL: none

TYPE AND VARIETY (IF KNOWN): Taylor Engraved 
SITE NAME OR SITE NUMBER: S. E. Watson

VESSEL NO.: 5

VESSEL FORM: Bowl or carinated bowl (Figure 6)

NON-PLASTICS AND PASTE: grog

RIM AND LIP FORM: Missing

CORE COLOR: F (fired in a reducing environment and cooled in the open air)

INTERIOR SURFACE COLOR: red

EXTERIOR SURFACE

COLOR: red

WALL THICKNESS

(IN MM): body, $5.9 \mathrm{~mm}$

INTERIOR SURFACE

TREATMENT: smoothed

EXTERIOR SURFACE

TREATMENT: smoothed

HEIGHT (IN CM): 5.0+

ORIFICE DIAMETER

(IN CM): 15.5

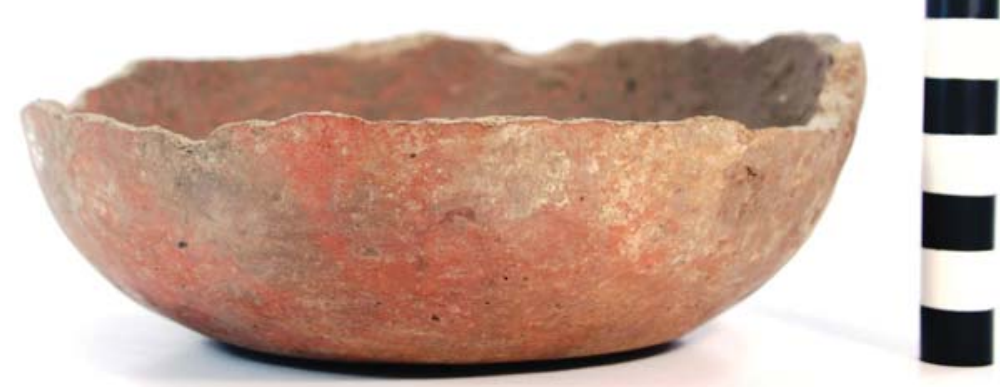

Figure 6. Sanders Slipped vessel from the S. E. Watson site.

DIAMETER AT BOTTOM OF RIM OR NECK (IN CM): N/A

BASE DIAMETER (IN CM) AND SHAPE OF BASE: 9.5; circular and flat

ESTIMATED VOLUME (IN LITERS): 0.4+

DECORATION (INCLUDING MOTIF AND ELEMENTS WHEN APPARENT): Both interior and exterior vessel surfaces have a red clay slip (Figure 6).

PIGMENT USE AND LOCATION ON VESSEL: none

TYPE AND VARIETY (IF KNOWN): Sanders Slipped (Perttula and Walters 2016) 
SITENAME OR SITENUMBER:S.E. Watson

VESSEL NO.: 7

VESSEL FORM: Bowl

NON-PLASTICS AND PASTE: grog

RIM AND LIP FORM: Inverted rim and rounded lip

CORE COLOR: B (fired and cooled in a reducing environment)

INTERIOR SURFACE COLOR:

very dark grayish-brown

EXTERIOR SURFACE COLOR:

very dark grayish-brown;

fire clouds on the body

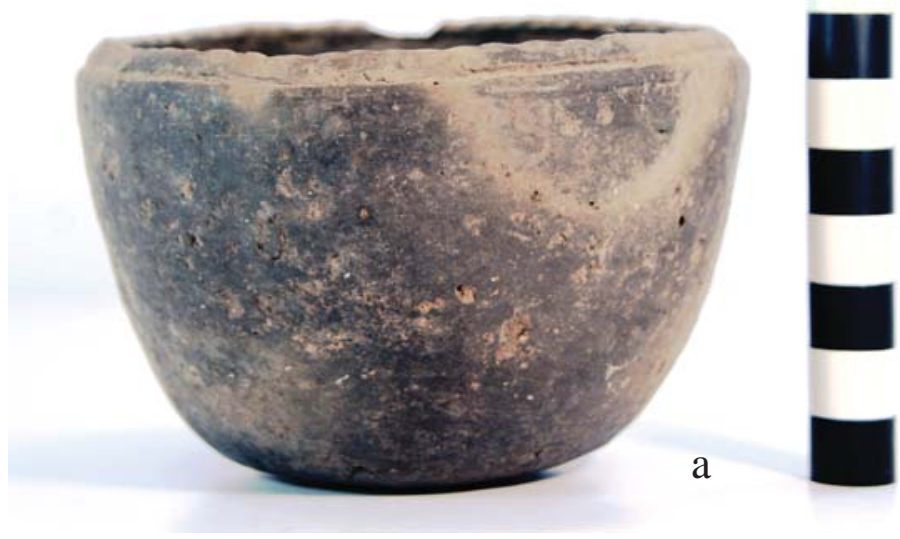

WALL THICKNESS (IN MM):

rim, $6.2 \mathrm{~mm}$

Figure 7. Simms Engraved bowl from the S. E. Watson site: a, side view; b, view of lip notching.

INTERIOR SURFACE

TREATMENT:

smoothed

EXTERIOR SURFACE

TREATMENT: burnished

HEIGHT (IN CM): 7.6

ORIFICE DIAMETER (IN CM): 9.0

DIAMETER AT BOTTOM OF RIM OR

NECK (IN CM): N/A

BASE DIAMETER (IN CM) AND SHAPE

OF BASE: 5.1; circular and rounded

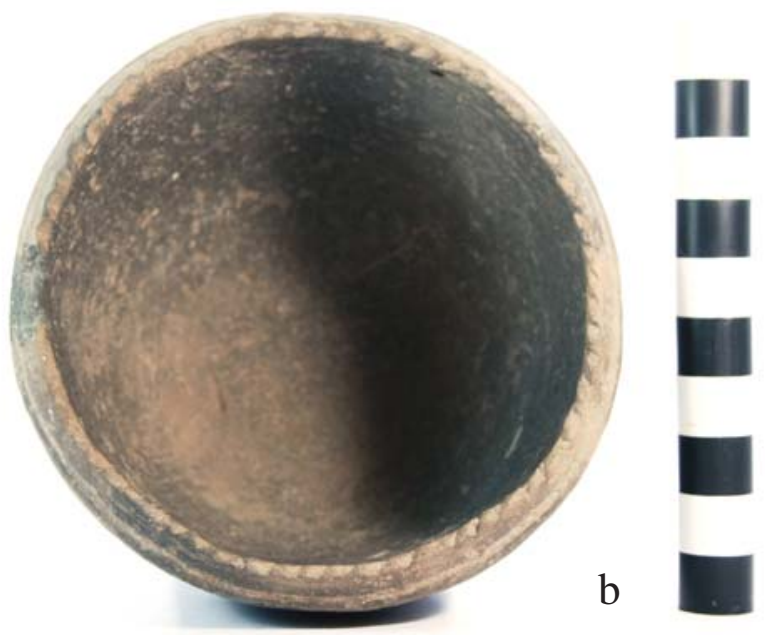

ESTIMATED VOLUME (IN LITERS): 0.3

DECORATION (INCLUDING MOTIF AND ELEMENTS WHEN APPARENT): The vessel lip is notched, and there is a single horizontal engraved line on the rim beneath the lip (Figure 7a-b).

PIGMENT USE AND LOCATION ON VESSEL: none

TYPE AND VARIETY (IF KNOWN): Simms Engraved 
SITE NAME OR SITE NUMBER: S. E. Watson

VESSEL NO.: 8

VESSEL FORM: Carinated bowl

NON-PLASTICS AND PASTE: grog

RIM AND LIP FORM: Inverted rim and rounded lip

CORE COLOR: F (fired in a reducing environment and cooled in the open air)

INTERIOR SURFACE COLOR: red

EXTERIOR SURFACE COLOR:

red; fire clouds on the body

WALL THICKNESS (IN MM):

rim, $4.4 \mathrm{~mm}$

INTERIOR SURFACE

TREATMENT: smoothed

EXTERIOR SURFACE

TREATMENT: burnished

HEIGHT (IN CM): 9.8

ORIFICE DIAMETER

(IN CM): 9.0

DIAMETER AT BOTTOM

OF RIM OR NECK (IN CM): 11.0

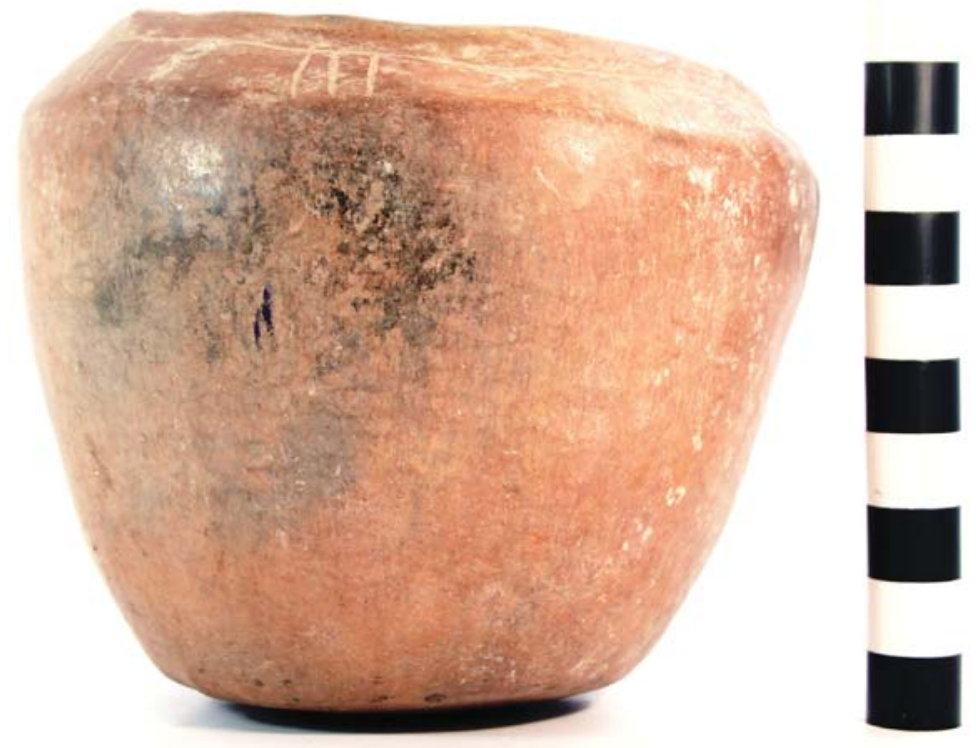

Figure 8. Simms Engraved carinated bowl from the S. E. Watson site.

BASE DIAMETER (IN CM) AND

SHAPE OF BASE: 6.3 ; circular and flat

ESTIMATED VOLUME (IN LITERS): 0.5

DECORATION (INCLUDING MOTIF AND ELEMENTS WHEN APPARENT): The rim has a single horizontal engraved line that runs mid-rim. Appended to this line are seven sets of three vertical engraved lines around the vessel (Figure 8).

PIGMENT USE AND LOCATION ON VESSEL: none

TYPE AND VARIETY (IF KNOWN): Simms Engraved 
SITE NAME OR SITE NUMBER: S. E. Watson

VESSEL NO.: 9

VESSEL FORM: Carinated bowl

NON-PLASTICS AND PASTE: grog

RIM AND LIP FORM: Direct rim and rounded, exterior folded, lip

CORE COLOR: F (fired in a reducing environment and cooled in the open air)

INTERIOR SURFACE

COLOR: brown

EXTERIOR SURFACE

COLOR: dark brown

WALL THICKNESS

(IN MM): rim, $5.9 \mathrm{~mm}$

INTERIOR SURFACE

TREATMENT: smoothed

EXTERIOR SURFACE

TREATMENT: smoothed

HEIGHT (IN CM): 7.5

ORIFICE DIAMETER

(IN CM): 12.5

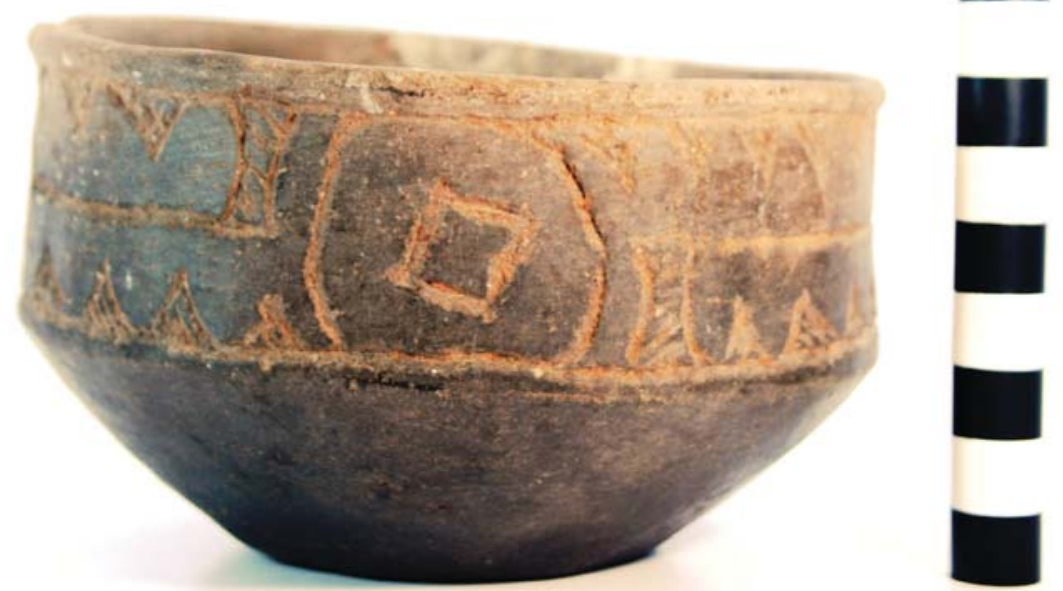

Figure 9. Ripley Engraved, var. McKinney carinated bowl from the S. E. Watson site.

\section{DIAMETER AT BOTTOM OF \\ RIM OR NECK (IN CM): 12.4}

BASE DIAMETER (IN CM) AND SHAPE OF BASE: 6.0; circular and flat

ESTIMATED VOLUME (IN LITERS): 0.6

DECORATION (INCLUDING MOTIF AND ELEMENTS WHEN APPARENT): The rim has two sets of horizontal engraved scrolls and circle elements. The circles have small inner diamond elements and there is a single diamond element midway on the horizontal scroll line. The ends of the scrolls are marked by upper and lower hatched vertical columns. Above and below the horizontal scroll lines are a series of hatched pendant triangles pointing either towards the rim or the vessel carination (Figure 9).

PIGMENT USE AND LOCATION ON VESSEL: none

TYPE AND VARIETY (IF KNOWN): Ripley Engraved, var. McKinney 
SITE NAME OR SITE NUMBER: S. E. Watson

VESSEL NO.: 10

VESSEL FORM: Jar with two strap handles (33 x $18 \mathrm{~mm}$ in height and width) (Figure 10), and the strap handles have two appliqued lip tabs

NON-PLASTICS AND PASTE: bone

RIM AND LIP FORM: Everted rim and rounded lip

CORE COLOR: G (fired in a reducing environment and cooled in the open air)

INTERIOR SURFACE COLOR: very dark grayish-brown

EXTERIOR SURFACE COLOR:

dark yellowish-brown; fire clouds

on the rim, body, and base

WALL THICKNESS

(IN MM): rim, $6.7 \mathrm{~mm}$

INTERIOR SURFACE

TREATMENT: none

EXTERIOR SURFACE

TREATMENT: none

HEIGHT (IN CM): 9.2

ORIFICE DIAMETER

(IN CM): 10.2

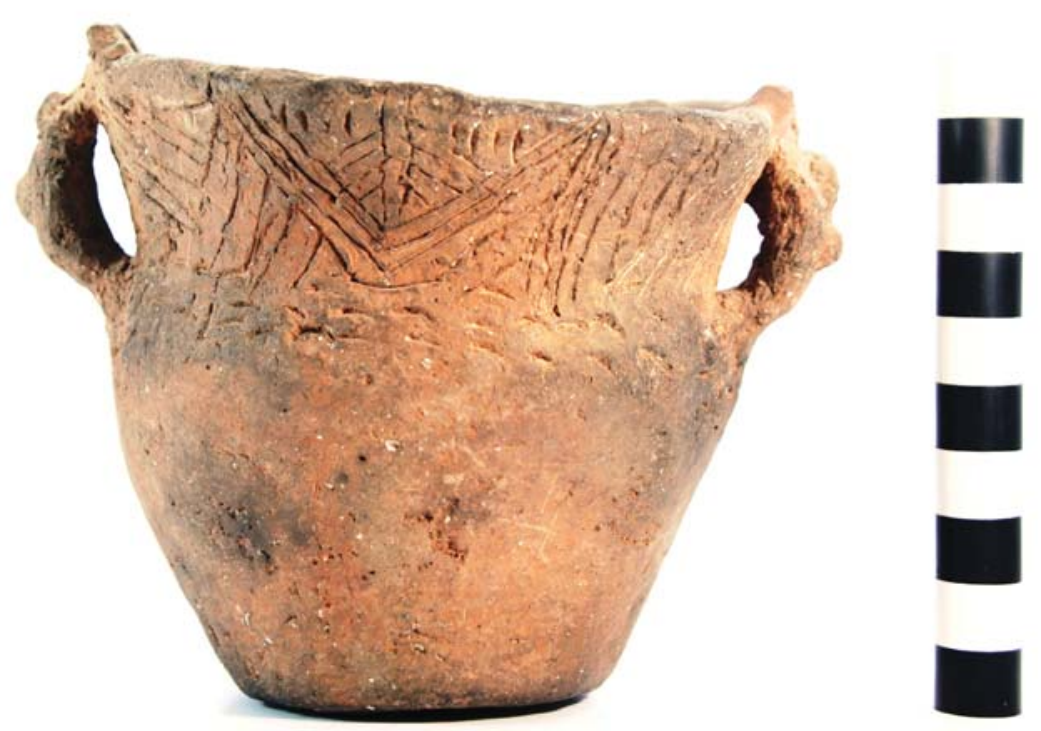

DIAMETER AT BOTTOM OF

Figure 10. Incised-punctated jar from the S. E. Watson site.

RIM OR NECK (IN CM): 9.6

BASE DIAMETER (IN CM) AND SHAPE OF BASE: 5.7; circular and flat

ESTIMATED VOLUME (IN LITERS): 0.6

DECORATION (INCLUDING MOTIF AND ELEMENTS WHEN APPARENT): The vessel rim is divided into two panels by the strap handles. These panels have sets of diagonal opposed, chevron, and vertical incised lines. The strap handles have a single vertical row of small appliqued nodes. The upper part of the vessel body has three horizontal rows of fingernail punctations (Figure 10).

PIGMENT USE AND LOCATION ON VESSEL: none

TYPE AND VARIETY (IF KNOWN): Unidentified utility ware 
SITE NAME OR SITE NUMBER: S. E. Watson

VESSEL NO.: 12

VESSEL FORM: Bottle with a short neck

NON-PLASTICS AND PASTE: grog

RIMAND LIPFORM: Directrim and rounded lip

CORECOLOR: $\mathrm{F}$ (fired in a reducing environment and cooled in the open air)

INTERIOR SURFACE COLOR: red (at the neck)

EXTERIOR SURFACE COLOR: red

WALL THICKNESS (IN MM): rim, $5.1 \mathrm{~mm}$

INTERIOR SURFACE TREATMENT: none

EXTERIORSURFACETREATMENT:burnished

HEIGHT (IN CM): 20.9

ORIFICE DIAMETER (IN CM): 4.4

DIAMETER AT BOTTOM OF RIM OR NECK (INCM): 5.5 ; maximum body diameter is $13.8 \mathrm{~cm}$.

BASE DIAMETER (IN CM) AND SHAPE OF

BASE: 7.5; circular and flat

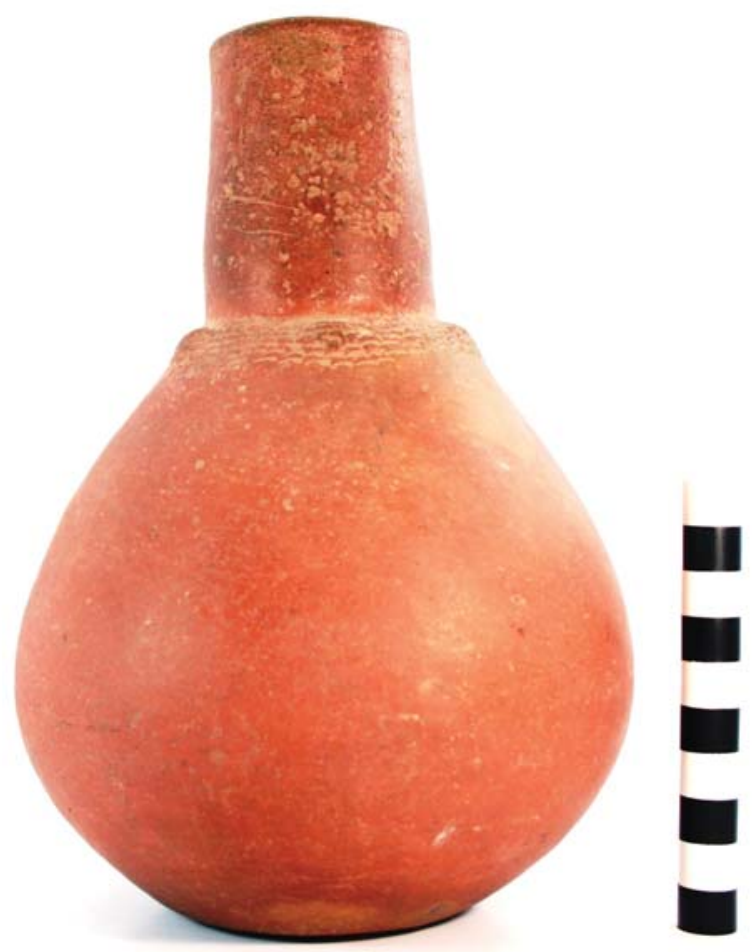

Figure 11. Maxey Noded Redware bottle from the S. E. Watson site.

ESTIMATED VOLUME (IN LITERS): 0.6

DECORATION (INCLUDING MOTIFAND ELEMENTS WHEN APPARENT): The exterior vessel surface and the interior vessel surface at the neck have a red clay slip. The vessel body has five horizontal rows of tool punctations between five large ( $9 \mathrm{~mm}$ in diameter) appliqued nodes (Figure 11).

PIGMENT USE AND LOCATION ON VESSEL: none

TYPE AND VARIETY (IF KNOWN): Maxey Noded Redware 
SITE NAME OR SITE NUMBER: S. E. Watson

VESSEL NO.: 13

VESSEL FORM: Jar

NON-PLASTICS AND PASTE: grog and bone

RIM AND LIP FORM: Missing

CORE COLOR: B (fired and cooled in a reducing environment)

INTERIOR SURFACE

COLOR: dark grayish-brown

EXTERIOR SURFACE

COLOR: grayish-brown;

fire clouds on the body and base

WALL THICKNESS

(IN MM): body, $4.4 \mathrm{~mm}$

INTERIOR SURFACE

TREATMENT: smoothed

EXTERIOR SURFACE

TREATMENT: none

HEIGHT (IN CM): 9.5+

ORIFICE DIAMETER

(IN CM): N/A

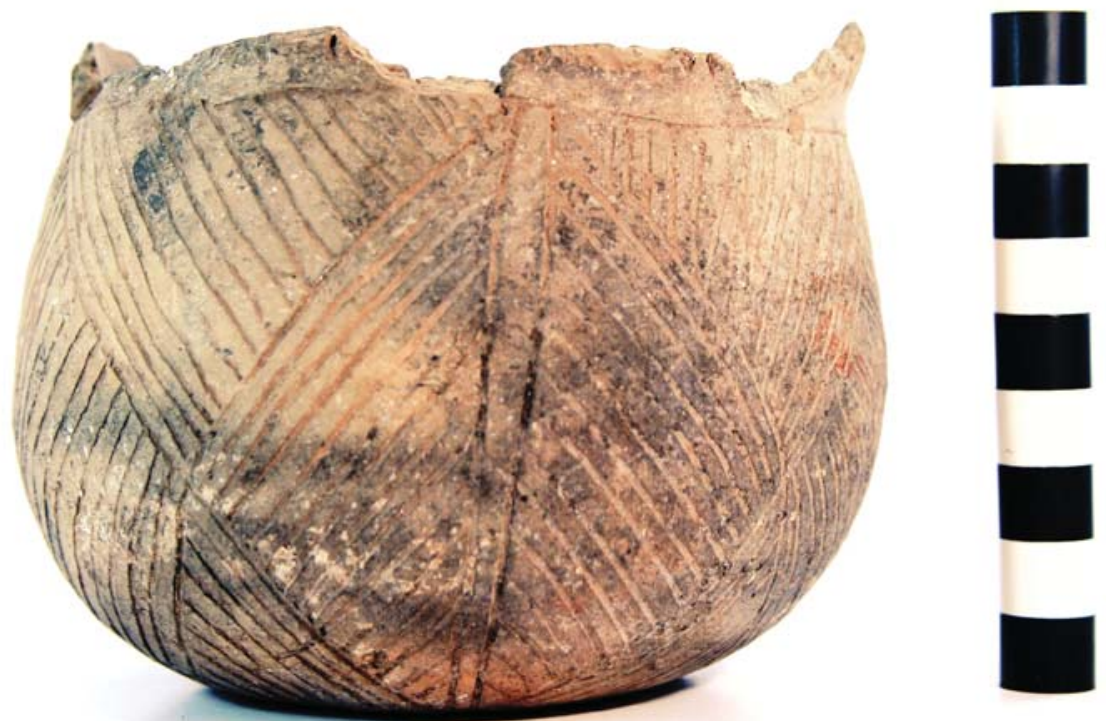

Figure 12. Pease Brushed-Incised jar from the S. E. Watson site.

DIAMETERATBOTTOMOF

RIM OR NECK (IN CM): 10.2, on body

BASE DIAMETER (IN CM) AND SHAPE OF BASE: 6.0; circular and flat

ESTIMATED VOLUME (IN LITERS): 0.6+

DECORATION (INCLUDING MOTIF AND ELEMENTS WHEN APPARENT): There is a single row of tool punctations at the base of the rim, just above the rim-body juncture. The vessel body is divided into four panels by sets of two closely-spaced vertical incised lines. The panels have four nested incised triangle elements filled with diagonal incised lines pitched in opposing directions (Figure 12).

PIGMENT USE AND LOCATION ON VESSEL: none

TYPE AND VARIETY (IF KNOWN): Pease Brushed-Incised 
SITE NAME OR SITE NUMBER: S. E. Watson

VESSEL NO.: 14

VESSEL FORM: Bottle with a spool neck

NON-PLASTICS AND PASTE: grog

RIM AND LIP FORM: Direct rim and rounded lip

CORE COLOR: B (fired and cooled in a reducing environment)

INTERIOR SURFACE COLOR:

very dark grayish-brown

EXTERIOR SURFACE COLOR:

dark grayish-brown

WALL THICKNESS (IN MM):

rim, $4.3 \mathrm{~mm}$

INTERIOR SURFACE

TREATMENT: none

EXTERIOR SURFACE

TREATMENT: smoothed

HEIGHT (IN CM): 7.6
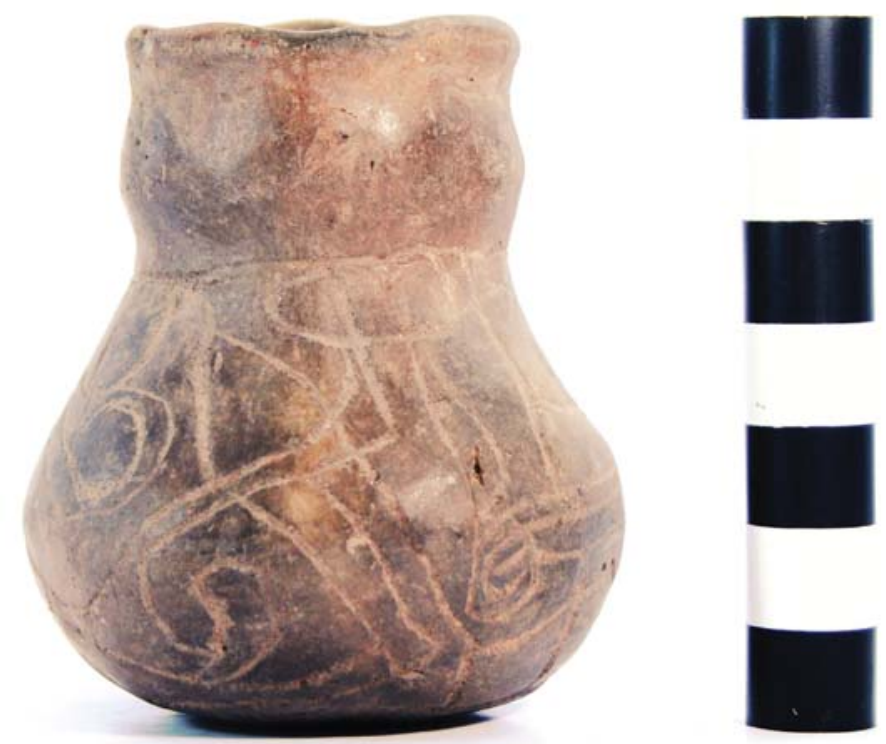

ORIFICE DIAMETER (IN CM): 3.3

Figure 13. Engraved bottle from the S. E. Watson site.

DIAMETER AT BOTTOM OF RIM OR NECK (IN CM): 3.5; maximum body diameter is $6.2 \mathrm{~cm}$.

BASE DIAMETER (IN CM) AND SHAPE OF BASE: 3.3; circular and flat

ESTIMATED VOLUME (IN LITERS): 0.1

DECORATION (INCLUDING MOTIF AND ELEMENTS WHEN APPARENT): The vessel body has an irregular arrangement of curvilinear and hooked arm elements - both horizontal and vertical in orientation - as well as horizontal, vertical, and curvilinear engraved lines and oval-shaped elements (Figure 13).

PIGMENT USE AND LOCATION ON VESSEL: none

TYPE AND VARIETY (IF KNOWN): Unidentified fine ware 
SITE NAME OR SITE NUMBER: S. E. Watson

VESSEL NO.: 23

VESSEL FORM: Deep bowl (Figure 14a)

NON-PLASTICS AND PASTE: grog

RIM AND LIP FORM: Inverted rim and flat lip

CORE COLOR: $\mathrm{F}$ (fired in a reducing

environment and cooled in the open air)

INTERIOR SURFACE COLOR: red

EXTERIOR SURFACE COLOR: red

WALL THICKNESS (IN MM):

rim, $5.1 \mathrm{~mm}$

INTERIOR SURFACE

TREATMENT: burnished

EXTERIOR SURFACE

TREATMENT: burnished

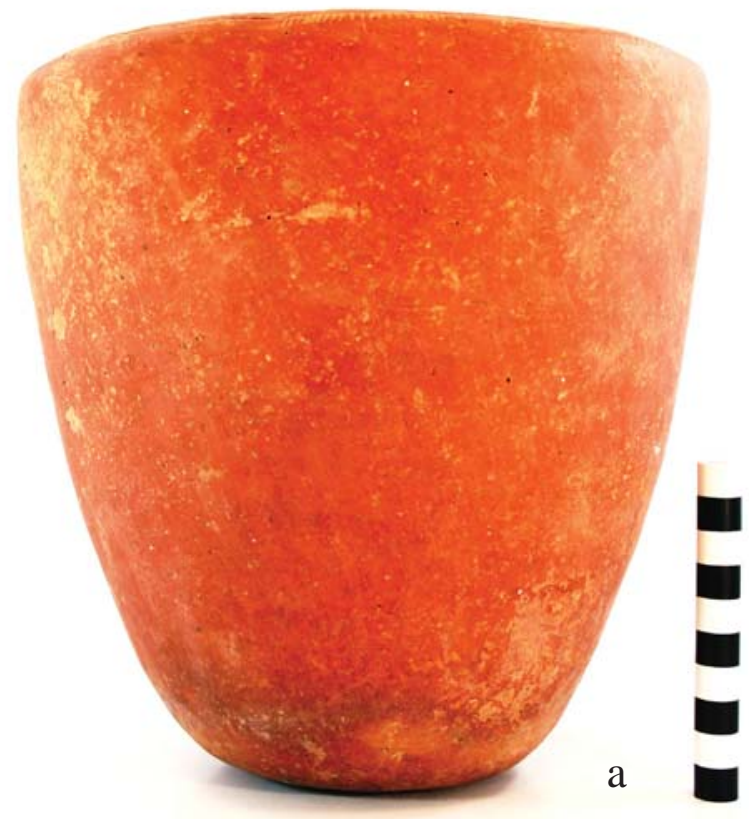

Figure 14. Simms Engraved deep bowl from the S. E. Watson site: a, side view; b, view of the vessel lip.

HEIGHT (IN CM): 21.8

ORIFICE DIAMETER (IN CM): 21.4

DIAMETER AT BOTTOM OF

RIM OR NECK (IN CM): N/A

BASE DIAMETER (IN CM) AND

SHAPE OF BASE: 8.9; circular and flat

ESTIMATED VOLUME (IN LITERS): 3.7

DECORATION (INCLUDING MOTIF AND ELEMENTS WHEN APPARENT): The rim is divided into four panels by sets of four opposed curvilinear engraved lines. The panels

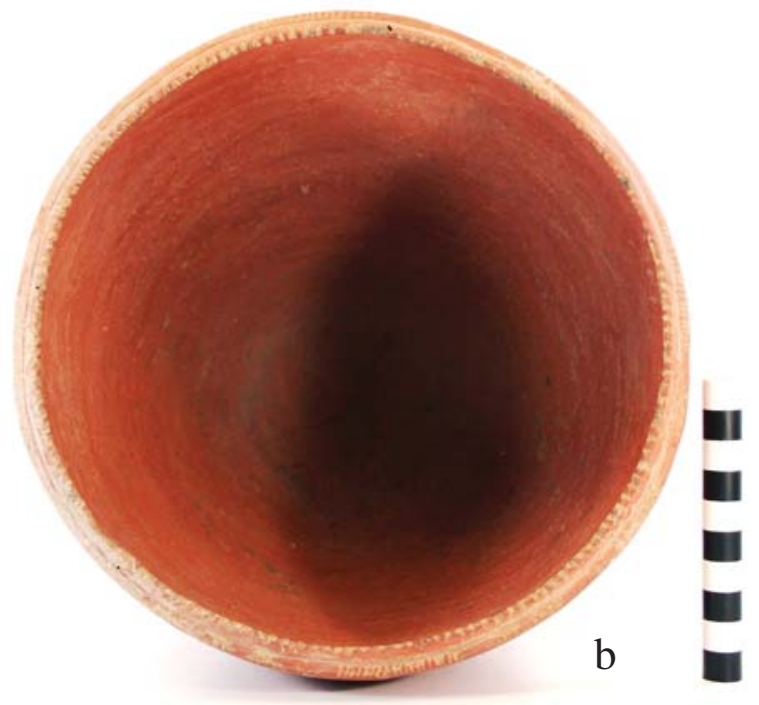
themselves have sets of closely-spaced and short vertical engraved lines. The vessel lip is also notched (Figure 14b).

PIGMENT USE AND LOCATION ON VESSEL: none

TYPE AND VARIETY (IF KNOWN): Simms Engraved 


\section{Hook's Ferry Site (41RR9) Vessel Documentation}

There are two Caddo ceramic vessels from the Hook's Ferry site in the TARL collections. They are from a Late Caddo McCurtain phase context, probably dating after ca. A.D. 1550. They were excavated in August 1930 by B. B. Gardner of The University of Texas.

SITE NAME OR SITE NUMBER: Hook's Ferry

VESSEL NO.: 1

VESSEL FORM: Bowl or Carinated bowl

NON-PLASTICS AND PASTE: shell

RIM AND LIP FORM: Missing

CORE COLOR: F (fired in a reducing environment and cooled in the open air)

INTERIOR SURFACE COLOR: red

EXTERIOR SURFACE COLOR: red

WALL THICKNESS (IN MM): body, $5.5 \mathrm{~mm}$; base, $6.3 \mathrm{~mm}$

INTERIOR SURFACE TREATMENT: smoothed

EXTERIOR SURFACE TREATMENT: burnished

HEIGHT (IN CM): 13.0+

ORIFICE DIAMETER (IN CM): N/A

DIAMETER AT BOTTOM OF RIM OR NECK (IN CM): 19.1 (on body)

BASE DIAMETER (IN CM) AND SHAPE OF BASE: 11.3; circular and flat

ESTIMATED VOLUME (IN LITERS): N/A

DECORATION (INCLUDING MOTIF AND ELEMENTS WHEN APPARENT): The interior and exterior vessel surfaces have a red clay slip.

PIGMENT USE AND LOCATION ON VESSEL: none

TYPE AND VARIETY (IF KNOWN): Clement Redware (Flynn 1976) 
SITE NAME OR SITE NUMBER: Hook's Ferry

VESSEL NO.: 2

VESSEL FORM: Bottle with a carinated body and a pedestal base

NON-PLASTICS AND PASTE: shell

RIM AND LIP FORM: Missing

CORE COLOR: B (fired and cooled in a reducing environment)

INTERIOR SURFACE COLOR: grayish-brown

EXTERIOR SURFACE COLOR: grayish-brown

WALL THICKNESS (IN MM): body, $4.6 \mathrm{~mm}$

INTERIOR SURFACE TREATMENT: none

EXTERIOR SURFACE TREATMENT: none

HEIGHT (IN CM): 17.6+ (body)

ORIFICE DIAMETER (IN CM): N/A

DIAMETER AT BOTTOM OF RIM

OR NECK (IN CM): 20.9 (body)

BASE DIAMETER (IN CM) AND

SHAPE OF BASE: 10.4; circular and flat

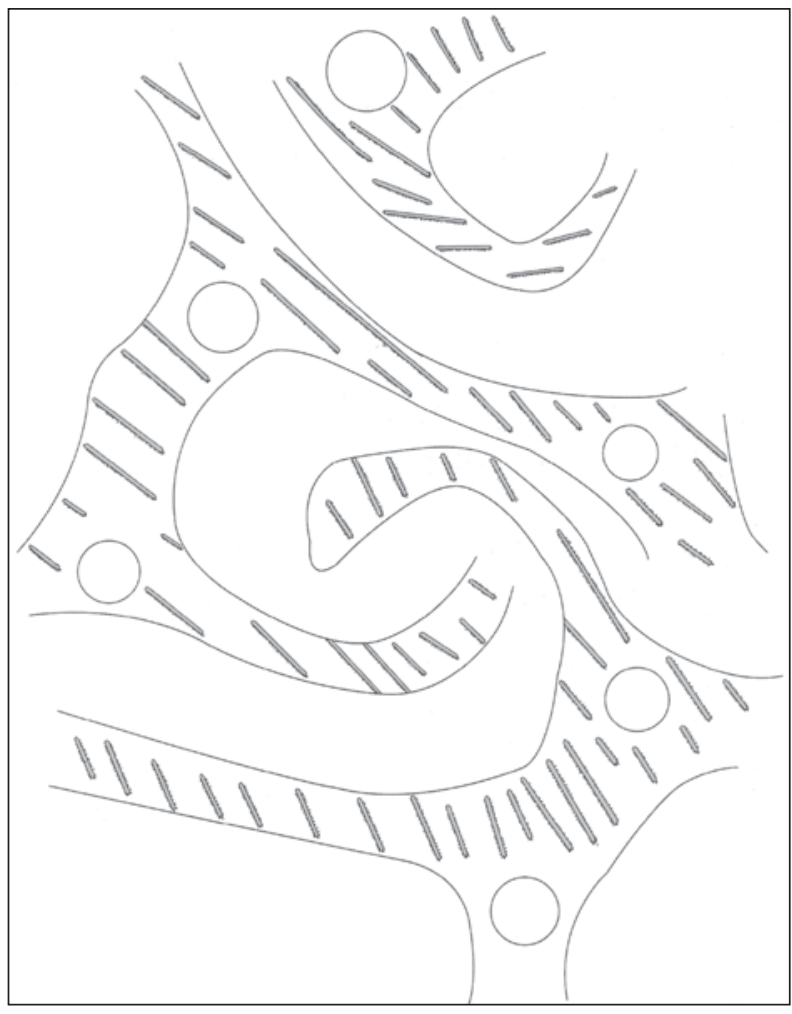

Figure 15. Hudson Engraved bottle from the Hook's Ferry site (41RR9).

ESTIMATED VOLUME (IN LITERS): N/A

DECORATION (INCLUDING MOTIF AND ELEMENTS WHEN APPARENT): The vessel body has an unknown series of engraved curvilinear zones with hooked arm that are filled with diagonal incised lines and a series of negative circle elements (Figure 15).

PIGMENT USE AND LOCATION ON VESSEL: none

TYPE AND VARIETY (IF KNOWN): Hudson Engraved 


\section{SUMMARY AND CONCLUSIONS}

The ceramic vessels from the S. E. Watson site appear to be from burial features that date to both the Middle Caddo period (ca. A.D. 1200) and the latter part of the McCurtain phase (postdating ca. A.D. 1550) in the Late Caddo period. The Middle Caddo vessels $(n=3)$ include a grog-tempered Sanders Slipped bowl or carinated bowl, a grog-tempered Maxey Noded Redware bottle with a short neck, and a grog- and bonetempered Pease Brushed-Incised jar. The late McCurtain phase vessels $(n=10)$ at the site are tempered with grog (80 percent), bone (10 percent), and shell (10 percent). Vessels of identifiable time include an Emory Punctated jar, a bone-tempered jar with strap handles and incised-fingernail punctated decorative elements on the rim and the upper vessel body, Simms Engraved bowls $(n=2)$, deep bowls $(n=1)$, and carinated bowls $(\mathrm{n}=1)$, including var. Darco, a Hodges Engraved bottle, a shell-tempered Taylor Engraved bowl, a cf. Taylor Engraved bottle with a spool neck, and a Ripley Engraved, var. McKinney carinated bowl.

Both of the ceramic vessels from the Hook's Ferry site (41RR9) are shell-tempered, indicating they are from a Late Caddo period, McCurtain phase burial, one likely to date after ca. A.D. 1600 because of the occurrence of a Hudson Engraved bottle in the collection. The other vessel is a red-slipped Clement Redware bowl or carinated bowl.

\section{ACKNOWLEDGMENTS}

Lance Trask and Sandra Hannum prepared the figures in this article. Thanks to Marybeth Tomka at the Texas Archeological Research Laboratory at The University of Texas at Austin for access to the vessel collections.

\section{REFERENCES CITED}

Flynn, P.

1976 A Study of Red-Filmed Pottery from the Clement Site (Mc-8), McCurtain County, Oklahoma. Bulletin of the Oklahoma Anthropological Society 25:127-134.

Perttula, T. K. and M. Walters

2016 Caddo Ceramic Vessels from the T. M. Sanders Site (41LR2) on the Red River in Lamar County, Texas. Special Publication No. 41. Friends of Northeast Texas Archaeology, Austin and Pittsburg. 